\title{
Procalcitonin versus C-Reactive Protein in Neonatal Sepsis
}

Ali $\mathrm{AM}^{\star 1}$, Elkhatib $\mathrm{WF}^{2,3}$ and Abdelaziz SS ${ }^{4}$

${ }^{1}$ Department of Pediatrics, Faculty of Medicine, International Islamic Center for Population Studies and Research, Al-Azhar University, Cairo, Egypt

${ }^{2}$ Department of Microbiology \& Immunology, Faculty of Pharmacy, Ain Shams University, African Union

Organization St. Abbassia, Cairo, Egypt

${ }^{3}$ Department of Pharmacy Practice, School of Pharmacy, Hampton University, Kittrell Hall Hampton, Virginia, USA

${ }^{4}$ Department of Urology, Faculty of Medicine, Al-Azhar University, Cairo, Egypt

${ }^{*}$ Corresponding author: Ali AM, Department of Pediatrics, Faculty of Medicine, Al-Azhar University, Cairo, Egypt, Postal Code: 31991, Dr. Noor Mohammad Khan General Hospital, Fax: +966713221417, Tel: +966556847829, E-mail: abdelrazak_ali@yahoo.com

Citation: Ali AM, Elkhatib WF, Abdelaziz SS (2014) Procalcitonin Versus C-Reactive Protein in Neonatal Sepsis. J Immunol Infect Dis 1(1): 103. doi: 10.15744/2394-6512.1.103

Received Date: May 28, 2014 Accepted Date: October 02, 2014 Published Date: October 07, 2014

\begin{abstract}
Objectives: To compare between C-reactive protein (CRP) and Procalcitonin (PCT) regarding diagnosis and outcome of neonatal sepsis.

Design: Prospective observational study.

Setting: Neonatal Intensive Care Unit (NICU).

Participants: Seventy newborn Infants admitted to NICU for sepsis management.

Results: Of the total 70 Neonates admitted in NICU, 31.4\%, $42.9 \%$ and $25.7 \%$ were categorized as proven sepsis, suspected sepsis and clinical sepsis respectively. Procalcitonin was positive in $100 \%$ compared to the CRP positivity in $63.6 \%$ of the proven sepsis cases. Mortality rate is significantly increased in proven sepsis compared to clinical sepsis.

Intervention: Sepsis workup laboratory tests.

Main Outcome Measures: Specific diagnostic and prognostic impact of the tests.

Conclusion: Comparing with CRP, PCT is not only a good diagnostic measure of neonatal sepsis but also effective predictor of sepsis outcome.
\end{abstract}

Keywords: Procalcitonin; CRP; Neonatal; Sepsis; UTI

\section{Background}

Urinary tract infection (UTI) is the most common serious bacterial infection in febrile children younger than 3 months, with reported rates ranging from $5 \%$ to $20 \%$ depending on different series. Neonates and infants up to age 2 months who have pyelonephritis usually do not have symptoms localized to the urinary tract. UTI is discovered as part of an evaluation for neonatal sepsis [1]. Neonatal sepsis is a clinical syndrome of systemic illness accompanied by bacteremia occurring in the first month of life. The overall incidence of primary sepsis is 1-5/1000 live births. The incidence is much higher for very low birth weight infants (birth weight $<1500 \mathrm{gm}$ ) [2]. Since the clinical manifestations of sepsis in neonates are non-specific and associated with high morbidity and mortality, early suspicion and treatment before blood culture confirmation is crucial [3]. The mortality rate is high (13-25\%) with higher rates seen in premature infants, those with early fulminant disease [2] and those with increasing severity of inflammation. The most severe infection is complicated by systemic inflammation and septic shock. However, to start therapy, an early reliable diagnosis is necessary [4]. Clinical signs and symptoms of infection often don't point towards the etiology. The diagnosis of sepsis is difficult because of non-specificity of clinical signs and symptoms and overlapping of symptoms with other noninfectious causes of systemic inflammation [5]. Elevated CRP levels are seen in infection, autoimmune disease, surgery, meconium aspiration and recent vaccination. Also, the CRP values do not rise significantly until almost 24-48 hr after the onset of infection [6,7].

Indeed, bacteriologic results need time and may be negative in newborns. Besides, it is impractical to blood sample for serial blood culture from infants [6,7]. So, a new laboratory methods for early diagnosis of the diseases, evaluation of prognosis and treatment efficiency are needed. CRP is one of the acute phase proteins. Although it is a classical and sensitive marker of inflammation; it cannot be used to differentiate between bacterial and other infections. It is a disadvantage that CRP increases after Procalcitonin (PCT) [8]. 
Furthermore, CRP doesn't reliably differentiate between the systemic inflammatory response and sepsis $[3,9]$. PCT is another recently focused biomarker, and in recent years it has established its role as a candidate marker for the diagnosis of systemic inflammation, infection, and sepsis; both in children and adults [5,10,11]. In1993, PCT was first described as a marker of the extent and course of systemic inflammatory response to bacterial and fungal infections [12].

PCT propeptide is the precursor protein of calcitonin and has no hormonal activity. It is a glycoprotein having 116 amino acids [13]. Normally it is produced by the $\mathrm{C}$ cells of the thyroid gland. In healthy persons procalcitonin levels are indetectably low. But in severe bacterial, fungal, parasitic infections with systemic manifestations, a significant rise in procalcitonin levels are seen. In this condition the production site is the extra thyroid tissues [14]

In healthy individuals, production of PCT and subsequently calcitonin is restricted to the thyroid C-cells. Bacterial infections selectively induce an increase in the concentration of PCT; because both endotoxins released from the bacterial cell wall as well as the host responses to infection activate the production of PCT mainly in parenchymal tissues. This results in accumulation of PCT, because unlike neuroendocrinal cells, parenchymal cells lack the ability to cleave PCT into its mature form calcitonin $[15,16]$. As such, the release of PCT into the circulation in large amounts in various disease states is not accompanied by significant rise in calcitonin levels.

\section{Methods}

This prospective study was conducted on neonates admitted for sepsis workup in Neonatal Intensive Care Unit, at Al-zahra General Hospital, Qatif, Saudi Arabia from June, 2011 to March, 2014. A total of 70 neonates with suspected sepsis who required sepsis evaluation on clinical basis were considered.

\section{Inclusion criteria}

Any suspected case of neonatal sepsis with maternal risk factors for sepsis e.g. prolonged labor, premature rupture of membrane (PROM) or prolonged PROM $>18$ hours, maternal intrapartum fever, urinary tract infection, chorioamnionitis and sepsis related clinical signs: (temperature instability, apnea, need for supplemental oxygen, bradycardia, tachycardia, hypotension /hypoperfusion, feeding intolerance, abdominal distension). Initially, Apgar score was used to indicate the infant condition in the first and fifth minutes after birth that includes: (appearance, heart rate, muscle tone, respiratory effort). Nosocomial infection is an infection whose development is favored by a hospital environment.

\section{Exclusion criteria}

There were administration of antibiotic therapy prior to admission, birth asphyxia, hyaline membrane disease, documented Necrotizing EnteroColitis (NEC), aspiration syndromes, laboratory finding suggestive of inborn error of metabolism, infant of diabetic mother, and congenital anomalies including congenital heart disease. Before starting antimicrobial therapy, blood samples (Sample 1) for, CBC, CRP, ESR, PCT and culture were collected. This procedure was repeated at day 5 after treatment with antibiotics (Sample 2). CSF, urine, tracheal and gastric aspirate cultures were obtained. Serum PCT level was measured using quantization immuno-luminometry by lumitest kit (Brahms Diagnostic, Berlin, Germany). The assay employs two antigen specific monoclonal antibodies, one directed at the calcitonin region which carries the luminescence label and the other at the katacalcin region. It is rapid and sensitive laboratory-based assay, providing results in $20 \mathrm{~min}$.

The detection limit for the assay is $0.1 \mathrm{ng} / \mathrm{mL}$ and the coefficient of variation between $1-1,000 \mathrm{ng} / \mathrm{mL}$ is $5-10 \%$. The assay is also free of interference from the antibiotics, sedatives, and vasoactive agents that are commonly used in ICU. PCT is present at very low levels, usually $<0.05 \mathrm{ng} / \mathrm{mL}$ and may be undetectable by some assays in healthy individual [17]. In this assay a PCT level of $\geq 0.5 \mathrm{ng} / \mathrm{ml}$ was accepted as pathological. PCT level $0.5-2 \mathrm{ng} / \mathrm{ml}, 2-10 \mathrm{ng} / \mathrm{ml}$ and $>10 \mathrm{ng} / \mathrm{ml}$ considered as weak positive, positive, and strong positive respectively. In contrast to bacterial and parasitic infections, only modest elevations of PCT are seen in viral infections. Consequently, serum PCT levels have been proposed as a marker to differentiate between viral and bacterial sepsis [18]. The study protocol was approved by the ethical committee Board and Informed parental consent for all infants. We used SPSS for statistical analysis. Pearson correlation between variables and statistical differences were analyzed using Fisher exact, ANOVA and Wilcoxon tests. P values of $<0.05$ were considered to be significant.

Criteria employed for defining the sepsis score are:

1. Group I, proven sepsis (22 cases): Clinical signs plus a positive bacterial culture.

2. Group II, suspected sepsis (30 cases): Clinical signs with negative bacterial culture but at least with 2 positive screening tests (ESR, CRP, CBC or CXR).

3. Group Ш, Clinical sepsis (18 cases): Clinical signs with negative bacterial culture and negative screening tests.

\section{Results}

A total of 70 newborns who met the inclusion criteria were eligible for the study. These neonates are classified into three groups; proven sepsis (22 cases), suspected sepsis (30 cases) and clinical sepsis (18 cases) according to the study protocol. Early onset sepsis was confirmed in 37 (52.8\%), late onset sepsis 20 (28.6\%) and nosocomial sepsis 13 (18.6\%). Blood culture was positive in 14 cases (Pathogens were Staphylococcus aureus, Group B Streptococcus, E. coli, and Klebsiella). Urine culture was positive in 4 (E coli, Staphylococcus epidermidis), positive CSF culture in 2 patients, (Group B Streptococcus, E. coli) and positive tip of chest tube in 2 patients, (Pseudomonas, Klebsiella). 
The demographic data of the proven, suspected and clinical septic groups are shown in Table 1. A statistically significant difference is observed between the mean birth weight and gestational age in proven and suspected septic groups in comparison with clinical septic group $(\mathrm{P}<0.05)$. Mortality rate is significantly increased in proven sepsis compared to clinical sepsis.

The mean of CRP and PCT in studied groups are shown; A significant difference between the mean of CRP and PCT levels in clinical and proven septic infants is noted $(\mathrm{P}<0.05)$. In addition, significant difference between proven sepsis and suspected sepsis, $(\mathrm{P}<0.05)$ is evident (Table 1$)$.

\begin{tabular}{|c|c|c|c|c|}
\hline Character & Proven sepsis & Suspected sepsis & Clinical sepsis & $P$-value \\
\hline Number & 22 & 30 & 18 & \\
\hline Birth weight $(\mathrm{g})$ & $2070 \pm 50$ & $2320 \pm 80$ & $2730 \pm 40$ & 0.02 \\
\hline GA (week) & $31.9 \pm 4$ & $33.9 \pm 3.6$ & $36.2 \pm 8.2$ & 0.04 \\
\hline Apgar score 1 & $6.3 \pm 2.3$ & $6.7 \pm 2.7$ & $8.1 \pm 1.3$ & 0.189 \\
\hline Apgar score 5 & $7.8 \pm 1.5$ & $8.4 \pm 2$ & $9.2 \pm 1$ & 0.157 \\
\hline Mortality & 7 & 6 & 3 & 0.002 \\
\hline CRP(Mean \pm SD), $\mathrm{mg} / 1$ & $23.17 \pm 32.7$ & $9.51 \pm 13.80$ & $4.82 \pm 2.76$ & $P<0.05$ \\
\hline PCT(Mean \pm SD), $\mathrm{ng} / \mathrm{ml}$ & $5.80 \pm 8.77$ & $3.06 \pm 5.84$ & $0.60 \pm 0.51$ & $P<0.05$ \\
\hline
\end{tabular}

The demographic data of the proven, suspected and clinical septic groups are shown; A statistically significant difference is observed between the mean birth weight and gestational age in proven and suspected septic groups in comparison with clinical septic group $(\mathrm{P}<0.05)$ Mortality rate is significantly increased in proven sepsis compared to clinical sepsis. There is a significant difference between the mean of CRP and PCT levels in clinical and proven septic infants $(\mathrm{P}<0.05)$

Table 1: Characteristics of the studied groups including, CRP and PCT serum levels.

Comparison of serum PCT level before and after treatment reveals significant changes in clinical sepsis $(\mathrm{P}=0.001)$ and proven sepsis $(\mathrm{P}=0.003)$ groups (Table 2). The relation between elevated procalcitonin levels and normal sepsis screening tests is represented in Table 3. In cases with proven sepsis, in spite of the negative result for sepsis screening tests, the result of PCT was positive. This result was seen also in some patients with clinical sepsis. The value of $\mathrm{R}$ is -0.3277 . Although statistically Pearson correlation test shows negative value, the relationship between variables is only weak (the nearer the value is to zero, the weaker the relationship). $\mathrm{P}$ Value is 0.673 . The result is not significant at $\mathrm{p}<0.05$.

\begin{tabular}{|c|c|c|c|c|c|c|}
\hline \multirow{2}{*}{ Group } & \multicolumn{2}{|c|}{ Proven sepsis } & \multicolumn{2}{c|}{ Suspected sepsis } & \multicolumn{2}{c|}{ Clinical sepsis } \\
\cline { 2 - 7 } & Before & After & Before & After & Before & After \\
\hline PCT test & & & & & & 16 \\
\hline Negative $($ PCT $<0.5 \mathrm{ng} / \mathrm{ml})$ & 0 & 0 & 7 & 22 & 4 & 1 \\
\hline Weak Positive $(\mathrm{PCT}=0.5-2 \mathrm{ng} / \mathrm{ml})$ & 0 & 0 & 2 & 0 & 3 & 1 \\
\hline Positive $(2-10 \mathrm{ng} / \mathrm{ml})$ & 2 & 1 & 15 & 7 & 10 & 1 \\
\hline Strong Positive $(\mathrm{PCT}>10 \mathrm{ng} / \mathrm{ml})$ & 20 & 2 & 6 & 1 & 1 & 0 \\
\hline
\end{tabular}

Comparison of serum PCT level before and after treatment reveals significant changes in clinical sepsis $(\mathrm{P}=0.001)$ and proven sepsis $(\mathrm{P}=0.003)$ groups.

Table 2: Serum procalcitonin level ( $\mathrm{ng} / \mathrm{ml})$ among studied groups before and after treatment.

\begin{tabular}{|c|c|c|c|}
\hline Sepsis Group & Clinical sepsis N=18 & Suspected Sepsis N=30 & Proven sepsis N=22 \\
\hline Normal ESR & 7 & 8 & 10 \\
\hline Normal CRP & 7 & 4 & 8 \\
\hline Normal WBCs & 17 & 10 & 12 \\
\hline Normal Chest X-Ray & 12 & 11 & 16 \\
\hline
\end{tabular}

WBC: White Blood Cell Count; CRP: C Reactive protein; ESR: Erythrocyte sedimentation rate.

In cases with proven sepsis, in spite of the negative result for sepsis screening test, the result of PCT was positive. This result was seen also in some patients with clinical sepsis. The value of $\mathrm{R}$ is -0.3277 . Although statistically there is a negative correlation, the relationship between variables is only weak the nearer the value is to zero, the weaker the relationship. P Value is 0.673 . The result is not significant at $\mathrm{p}<0.05$.

Table 3: Relation between elevated procalcitonin levels and normal sepsis screening tests.

\section{Discussion}

In recent years measurement of procalcitonin and other inflammatory mediators have been reported as a sensitive parameters for the early diagnosis of neonatal sepsis and evaluating its outcome [19]. Proinflammatory cytokines plays a role in the pathogenesis of bacterial sepsis. Production of these cytokines seems to trigger procalcitonin secretion from target cells. The increase in the serum concentration of CRP is rather slow during the first $24-48 \mathrm{hr}$ of infection and this may negatively affect the sensitivity of the test. In addition, increase CRP concentrations in non-clinical conditions in such as meconium aspiration, prolonged rupture of membranes are thought to affect the specificity of the test [20]. 
PCT levels more than $0.5 \mathrm{mg} / \mathrm{dl}$ are useful to determine the type of infectious process (bacterial or not) [20]. In our study all the patients that presented positive cultures had PCT levels greater than $0.5 \mathrm{mg} / \mathrm{dl}$ and in most of them were greater than $2 \mathrm{mg} / \mathrm{dl}$. The correlation of PCT with culture was highly significant $(\mathrm{p}=0.004)$ and the relative risk was much greater than with CRP values. This is fundamental because by having this clear determination it is feasible to initiate early and efficient therapy prior to the infectious process being evident or having a positive culture. Thus, the sepsis related morbidity and mortality could be greatly reduced.

Our findings demonstrated that the mortality rate is significantly increased in proven sepsis, particularly if PCT levels greater than $10 \mathrm{ng} / \mathrm{ml}$, so it is possible to predict a prognosis. The potential mortality related to other confounder in our study such as decreased gestational age, is unlikely to be anticipated as the decreased age per se (31-37 weeks gestation) could not affect the mortality. However, the prematurity related complications are those which are potentially responsible for mortality. Similarly, Brunkhorst et al. [21], have even demonstrated that very high PCT values are related to septic shock and death with considering a bad prognostic values greater than $10 \mathrm{ng} / \mathrm{dl}$. Nonetheless more studies should be made to demonstrate that early therapy with higher PCT and CRP values can reduce mortality.

A study in Denmark clarified that patients with septic process present less mortality risk with PCT levels less than 1mg/dl, and increments in this value of more than, $1 \mathrm{mg} / \mathrm{dl}$ per day are associated with an increment in mortality [22]. The results reported that the correlation of the PCT levels with those of CRP was not statistically significant. The relative risk of mortality with CRP was significant with values greater than $128 \mathrm{mg} / \mathrm{dl}$. When these values are compared with current literature it is possible to affirm that patients with CRP levels greater than $128 \mathrm{mg} / \mathrm{dl}$ have a greater risk of death.

In an Australian study a cohort value for the CRP values was obtained, mentioning a 7\% risk of death with levels greater than $150 \mathrm{mg} / \mathrm{dl}$ and up to $21 \%$ when levels are greater than $300 \mathrm{mg} / \mathrm{dl}$ [23]. With regards to the utility of CRP as a prognostic marker, the majority of studies failed to demonstrate any correlation between CRP concentration and the survival [24].

Nonetheless, Vincent et al. (1996) [25] confirmed the relationship between CRP concentrations, severity of multiple organic dysfunction and mortality. PCT has been intensively investigated for its diagnostic role in neonatal sepsis. It has been reported that high concentration of plasma PCT was found in infants with severe infection, while PCT levels were very low in those without infections [26]. Many authors found that procalcitonin are a promising marker for the diagnosis of neonatal sepsis [9,27,28].

In these studies, PCT sensitivity in the early diagnosis of neonatal sepsis was found to be $83-100 \%$ while the specificity was 70 $100 \%[9,27,28]$ but some investigators questioned the accuracy of PCT in detecting neonatal sepsis. In these studies, it was reported that serum levels had also increased in non-infected neonates with perinatal asphyxia, intracranial hemorrhage, pneumothorax, or after resuscitation, and these conditions had negatively affected the specificity of PCT [29,30].

However, the protocol of our study implemented exclusive criteria that omit the influence of noninfectious confounders. Blommendahl et al. [31] reported that although the PCT test appeared to be useful for the diagnosis of neonatal sepsis in his small study, it didn't offer any significant advantages over traditional test like CRP for the diagnosis of sepsis, and this is consistent with other study conducted by Naher BS et al. [8] which concluded that PCT test can be done as an additional test with CRP for the diagnosis of neonatal sepsis, but the small sample size of those studies may limit drawing any firm conclusions. Thus, it is clear that the apparent discrepancy between the various studies performed so far could be explained by the geographical differences in infection patterns within the population, the possible interference of other confounders or variations in the study design and bias.

It is postulated that cytokines are prognostic for the development of severe disease, sepsis and death in hospitalized patients. The elevated concentrations of cytokines and markers reflect the complex changes in the immune response to microorganisms that are associated with alterations of the neuroendocrinal and vascular systems [32]. In short, both endotoxins released from the bacterial cell wall as well as the host responses to infection activate the production of PCT in parenchymal tissues. Accordingly, the more severe infection is the more production of cytokines and PCT, the more alterations of the neuroendocrine-vascular axis, and consequently the increased level of mortality would be the outcome.

\section{Conclusions}

Comparing with CRP, Procalcitonin is not only a good diagnostic measure of neonatal sepsis but also effective predictor of sepsis outcome.

\section{References}

1. Morley EJ, Lapoint JM, Roy LW, Cantor R, Grant WD, et al. (2012) Rates of positive blood, urine, and cerebrospinal fluid cultures in children younger than 60 days during the vaccination era. Pediatr Emerg Care 28: 125-30.

2. Gomella TL, Cunningham MD, Eyal GF (2013) Neonatology Management, Procedures, On-call Problems, Diseases, and Drugs, (7 $7^{\text {th }}$ edn), McGraw-Hill Education Publisher, Ohio, USA.

3. Andrejaitiene J (2006) The diagnostic value in severe sepsis. Medicina Kaunas 42: 69-78.

4. Angus DC, Linde-Zwirble WT, Lidicker J, Clermont G, Carcillo J, et al. (2001) Epidemiology of severe sepsis in the United States: Analysis of incidence, outcome, and associated costs of care. Crit Care Med 29: 1303-10.

5. Kaur K, Mahajan R, Tanwar A (2013) A novel marker procalcitonin may help stem the antibiotic overuse in emergency setting. Int J Appl Basic Med Res 3: 77-83.

6. Ng P (2004) Diagnostic markers of infection in neonates. Arch Dis Child Fetal Neonatal Ed 89: F229-35.

7. Weinschenk NP, Farina A, Bianchi DW (2000) Premature infants respond to early-onset and late-onset sepsis with leukocyte activation. J Pediatr 137: 345-50. 
8. Naher BS, Mannan MA, Noor K, Shahiddullah M (2011) Role of serum procalcitonin and C-Reactive Protein in the diagnosis of neonatal sepsis. Bangl Med Res Counc Bull 37: 40-6.

9. Carrol CD, Thomson APJ, Hart CA (2002) Procalcitonin as a marker of sepsis. Int J Antimicrob Agents 20: 1-9.

10. Manzano S, Bailey B, Gervaix A, Cousineau J, Delvin E, et al. (2011) Markers for bacterial infection in children with fever without source. Arch Dis Child 96: $440-6$.

11. Singh JC, Kekre NS (2006) Procalcitonin: A marker of renal parenchymal infection in children? Ind J Urol 22: 162-3.

12. Assicot M, Gendrel D, Carsin H, Raymond J, Guilbaud J, et al. (1993) High serum procalcitonin concentrations in patients with sepsis and infection. Lancet 341: 515-8.

13. Whicher J, Bienvenu J, Monneret G (2001) Procalcitonin as an acute phase marker. Ann Clin Biochem 38: 483-93.

14. Snider RH, Nylen ES, Becker KL (1997) Procalcitonin and its component peptides in systemic inflammation: immunochemical characterization. J Invest Med 45: 552-60.

15. Linscheid P, Seboek D, Schaer DJ, Zulewski H, Keller U, et al. (2004) Expression and secretion of procalcitonin and calcitonin gene-related peptide by adherent monocytes and by macrophage-activated adipocytes. Crit Care Med 32: 1715-21.

16. Becker KL, Nylén ES, White JC, Müller B, Snider RH (2004) Clinical review 167: Procalcitonin and the calcitonin gene family of peptides in inflammation, infection, and sepsis: a journey from calcitonin back to its precursors. J Clin Endocrinol Metab 89: 1512-25.

17. Braithwaite S (2000) Procalcitonin: New insights on regulation and origin. Crit Care Med 28: 586-8.

18. Schwarz S, Bertram M, Schwab S, Andrassy K, Hacke W (2000) Serum procalcitonin levels in bacterial and abacterial meningitis. Crit Care Med 28: 1828-32.

19. Lachowska M, Gajewska E (2004) Usefulness of procalcitonin (PCT) as a marker of early-onset systemic infections in preterm newborns. Med Sci Monit 10: $33-5$.

20. Kocabas E, Sarıkçıoglu A, Aksaray N, Seydaoğlu G, Seyhun Y, et al. (2007) Role of procalcitonin, C-reactive protein, interleukin-6, interleukin-8 and tumor necrosis factor-alpha in the diagnosis of neonatal sepsis. Turk J Pediatr 49: 7-20.

21. Brunkhorst FM, Wegscheider K, Forycki ZF, Brunkhorst R (2000) Procalcitonin for early diagnosis and differentiation of SIRS, sepsis, severe sepsis, and septic shock. Inten Care Med 26: S148-52.

22. Jensen JU, Heslet L, Jensen TH, Espersen K, Steffensen P, et al. (2006) Procalcitonin increase in early identification of critically ill patients at high risk of mortality. Crit Care Med 34: 2596-602.

23. Seller-Pérez G, Herrera-Gutiérrez ME, Lebrón-Gallardo M, Toro-Peinadob ID, Martín-Hita L, et al. (2005) Valor. de la determinación de la proteína C reactiva como marcador Pronóstico y de infección en pacientes críticos. Med Clin 125: 761-5.

24. Pettilä V, Pentti J, Pettilä M, Takkunen O, Jousela I (2002) Predictive value of antithrombin III and serum CRP concentration in critically ill patients with suspected sepsis. Crit Care Med 30: 271-5.

25. Vincent JL, Moreno R, Takala J, Willatts S, De Mendonça A, et al. (1996) The SOFA (Sepsis-related Organ Failure Assessment) score to describe organ dys function/ failure. On behalf of the Working Group on Sepsis-Related Problems of the European Society of Intensive Care Medicine. Intens Care Med 22: 707-10.

26. Chiesa C, Panero A, Rossi N, Stegagno M, De Giusti M, et al. (1998) Reliability of procalcitonin concentrations for the diagnosis of sepsis in critically ill neonates. Clin Inf Dis 26: 664-72.

27. Vincent JL (2000) Procalcitonin: THE marker of sepsis? Crit Care Med 28: 1226-8.

28. Gendrel D, Raymond J, Coste J, Moulin F, Lorrot M, et al. (1999) Comparion of procalcitonin with C-reactive protein, interleukin 6 and interferon-alpha for differentiation of bacterial vs. viral infections. Pediatr Inf Dis J 18: 875-81.

29. Monneret G, Labaune JM, Isaac C, Bienvenu F, Putet G, et al. (1997) Procalcitonin and C-reactive protein levels in neonatal infections. Acta Paediatr 86: 209-12.

30. Janota J, Stranak Z, Belohlavkova S, Mudra K, Simak J (2001) Postnatal increase of procalcitonin in premature newborns is enhanced by chorioamnionitis and neonatal sepsis. Eur J Clin Invest 31: 978-83.

31. Blommendahl J, Janas M, Laine S, Miettinen A, Ashorn P (2002) Comparison of procalcitonin with CRP and differential white blood cell count for diagnosis of culture-proven neonatal sepsis. Scand J Inf Dis 34: 620-2.

32. Borovac DN, Pejcic T, Petkovic TR, Dordevic V, Dordevic I, et al. (2011) New Markers in Prognosis of Severe Community -Acquired Pneumonia. Sci J Faculty of Medicine 28: 147-54. 